\title{
Prevalence of organic gunshot residues in police vehicles
}

\author{
Anne-Laure Gassner, Céline Weyermann \\ School of Criminal Sciences, University of Lausanne, Switzerland
}

\begin{abstract}
The present study investigated the organic gunshot residue (OGSR) background level of police vehicles in Switzerland. Specimens from 64 vehicles belonging to two regional police services were collected and analysed by LC-MS in positive mode. The driver's and back seats were sampled separately to monitor potential differences between locations and to assess the risks of a suspect being contaminated by OGSR during transportation to a police station.

The results showed that most of the 64 vehicles were uncontaminated (44 driver's seats and 38 back seats respectively). Up to six of the seven targeted compounds were detected in a single sample, once on a driver's seat and twice on back seats. The contamination frequency generally decreased as the number of compounds detected together increased. The amounts detected were in the low ng range and less than amounts generally detected just after discharge on a shooter. Our data indicated that detecting a combination of four or more compounds on a police vehicle seat appears to be a relatively rare occurrence. The background contamination observed was most probably due to secondary transfer from police officers (e.g. through recent participation in a shooting session or firearm manipulation) or from firearms stored in the vehicles. The present results might be used as a recommendation to minimize contact of a suspect with contaminated surfaces if OGSR is implemented in routine work in parallel to IGSR analysis.
\end{abstract}

Keywords: Forensic science, firearm discharge residue, background, contamination, LC-MS 


\section{INTRODUCTION}

Gunshot residues (GSR) are one of the forensically relevant traces produced by the discharge of a firearm. The residues consist of vapour and particulate matter expelled mainly from the muzzle, but also from other firearm openings, that might deposit onto the target, the shooter, potential bystanders and objects close to the firearm $[1,2]$. The production and transfer of GSR depend on a number of factors such as the type of firearm, the ammunition, the number of shots fired, the properties of the recipient material and the environmental conditions [3]. While in casework GSR are frequently used to estimate the shooting distance or distinguish entrance and exit wounds, they also help in assessing the potential involvement of an individual in a shooting incident [4, 5]. Inorganic GSR (IGSR) mainly originate from the primer and other metallic parts of the firearm and ammunition (i.e. barrel, bullet and cartridge case), whereas organic GSR (OGSR) are produced by incomplete combustion of the propellant [4-6]. While IGSR are routinely analysed in forensic laboratories using scanning electron microscopy coupled to energy dispersive X-ray spectroscopy (SEM-EDX) [1, 4], OGSR analysis is still rarely applied in casework. This may be explained by the absence of a standardised protocol (collection, extraction and analysis), as several analytical methods have been proposed and investigated for the analysis of propellants and OGSR without one outperforming the others in all particulars. Spectroscopic techniques, such as Raman [7-9], Fourier transformed infrared spectroscopy (FTIR) [10,11] or ion mobility spectrometry (IMS) [12-14] detect OGSR based on spectral information, without formal compound identification. While these methods are non-destructive, their sensitivity remains limited (IMS) or is yet to be demonstrated on real specimens (Raman, FTIR). On the contrary, bulk analytical techniques such as micellar electrokinetic capillary electrophoresis (MEKC) [15-18], gas chromatography (GC) [19-21] or liquid chromatography coupled to mass spectrometry (LC-MS) [22-27], separate and identify the compounds, can be very sensitive, but involve the dissolution of the specimen.

Studies showed that GSR are lost relatively quickly from the hands, even without washing, resulting in very low amounts still remaining on a shooter's hands a few hours after discharge [1]. Thus, very sensitive analytical techniques are required. Recent OGSR forensic studies utilizing LC-MS analysis have demonstrated the detection of OGSR on the hands of a shooter up to four hours after discharge [28] and highlighted secondary transfer in several scenarios [29, 30]. Currently, OGSR can be detected at the sub-picogram level, due to major improvements in MS sensitivities in the last decade. Moreover, new technical developments are expected and should further enhance detection capabilities using LCMS, increasing the potential of this technique for the analysis of OGSR. However, sensitivity improvements generally lead to increased background signal, requiring careful interpretation of the results and evaluation of the various activities that can produce such traces.

The interpretation of GSR evidence requires background or prevalence studies in relevant populations, which are case- and country-specific. GSR prevalence can depend on occupation, living area (city/countryside, known firearm violence), and firearm possession (legal and illegal) but also on the population type, e.g. individuals vs objects (clothing, vehicles, public places). For example, the 
probability of finding GSR on the hands of a police officer who carries a service weapon and regularly practices shooting might be higher than on a citizen with absolutely no contact with firearms. Consequently, the evidentiary value of a GSR trace will vary accordingly with the case circumstances and the explanation provided by the defense [31]. Background studies in a police environment might also play a role in police management. Indeed, monitoring the GSR background would highlight potential risks of secondary transfer from police officers and premises, thus helping in establishing procedures to avoid such transfer to individuals arrested, transferred in police vehicles and detained in police facilities.

72 Various background studies have been conducted, targeting IGSR and/or OGSR (Table 1). However, 73 their number remains relatively limited. Other types of studies aiming at reconstructing events of a shooting case have also been reported. For example, a simulation of shooting was carried out to quantitate GSR contamination of a car's interior surfaces when a firearm was discharged within a car, showing a significant amount of characteristic IGSR particles on the window headliner and dashboard [32]. 
Table 1: Summary of background/prevalence studies targeting IGSR and/or OGSR

\begin{tabular}{|c|c|c|c|c|c|c|c|}
\hline Reference & GSR type & Population type & Population size & Country & Surface sampled & Analytical technique & Main results \\
\hline $\begin{array}{l}\text { Gialamas et al, } \\
1995[33]\end{array}$ & IGSR & Police & 43 & USA & Hands & SEM-EDX & $\begin{array}{l}\text { - } 3 \text { specimens with one } \mathrm{PbBaSb} \text { particle in a population of } 43 \text { non-shooting } \\
\text { police officers }\end{array}$ \\
\hline $\begin{array}{l}\text { Berk et al, } 2007 \\
{[34]}\end{array}$ & IGSR & Police & 201 & $\overline{\text { USA }}$ & $\begin{array}{l}\text { Vehicles and } \\
\text { detention facilities }\end{array}$ & SEM-EDX & $\begin{array}{l}\text { - } \text { total of } 56 \mathrm{PbBaSb} \text { particles found in } 23 \text { specimens } \\
\text { - } \\
\text { - } \\
\text { two vehicles with one particle } \\
\text { particles collected from a table surface and restraining bars }\end{array}$ \\
\hline $\begin{array}{l}\text { Lindsay et al, } \\
2011[35]\end{array}$ & IGSR & $\begin{array}{l}\text { Firearm } \\
\text { manufacture } \\
\text { employees }\end{array}$ & 13 & Canada & Hands & SEM-EDX & $\begin{array}{l}\text { - } \mathrm{PbBaSb} \text { particles found on nine of the employees } \\
\text { - no more than two characteristic particles found on the hands of the five } \\
\text { individuals who had no direct contact with firearms } \\
\text { - for the other four employees: number of particles from nine to } 424\end{array}$ \\
\hline $\begin{array}{l}\text { Gerard et al, } \\
2012[36]\end{array}$ & IGSR & Police & $\begin{array}{l}66 \text { police officers } \\
28 \text { civilians } \\
\text { working in police } \\
\text { environment } \\
18 \text { vehicles }\end{array}$ & Canada & $\begin{array}{l}\text { Hands, clothes, } \\
\text { equipment and } \\
\text { vehicles }\end{array}$ & SEM-EDX & $\begin{array}{l}\text { - at least one PbBaSb particle on the hands of } 60 \% \text { of patrol and plainclothes } \\
\text { officers and on } 24 \% \text { of their equipment } \\
\text { - } \quad \text { no IGSR particles found on the } 28 \text { civilians working in a police environment } \\
\text { - } 2 \text { of the } 18 \text { vehicles sampled had one characteristic GSR particle }\end{array}$ \\
\hline $\begin{array}{l}\text { Brozek-Mucha, } \\
2014 \text { [37] }\end{array}$ & IGSR & Civilian \& police & $\begin{array}{l}50 \text { shooters } \\
100 \text { non-shooters }\end{array}$ & Poland & Hands & SEM-EDX & $\begin{array}{l}\text { - one PbBaSb particle detected among individuals who had no contact with } \\
\text { firearms } \\
\text { - numerous particles found among shooters showing a strong correlation with } \\
\text { the time elapsed since the last shooting session }\end{array}$ \\
\hline $\begin{array}{l}\text { Hannigan et al, } \\
2015[38]\end{array}$ & IGSR & Arrested people & 100 & Ireland & $\begin{array}{l}\text { Upper body } \\
\text { garments }\end{array}$ & SEM-EDX & $\begin{array}{l}\text { - } 98 \% \text { of the specimens collected from the cuffs negative } \\
\text { - } \quad \text { up to two PbBaSb particles detected on two garments }\end{array}$ \\
\hline Cook, 2016 [39] & IGSR & Police & 33 & Australia & Hands & SEM-EDX & $\begin{array}{l}28 \text { officers with } \mathrm{PbBaSb} \text { particles on their hands, with an average of } 64 \text { such } \\
\text { particles }\end{array}$ \\
\hline $\begin{array}{l}\text { Lucas et al, } 2016 \\
{[40]}\end{array}$ & IGSR & Civilian & 289 & Australia & Hands & SEM-EDX & $\begin{array}{l}\text { - overall prevalence of } 0.3 \% \text { for characteristic } \mathrm{PbBaSb} \text { particles, } 8 \% \text { for } \mathrm{PbSb} \\
\text { and about } 7 \% \text { for single } \mathrm{Pb} \text {, Ba or } \mathrm{Sb} \text { particles }\end{array}$ \\
\hline $\begin{array}{l}\text { Comanescu et al, } \\
2019[41]\end{array}$ & IGSR & Civilian & 50 & USA & Vehicles & $\begin{array}{l}\text { Graphite Furnace } \\
\text { Atomic Absorption }\end{array}$ & - $\quad$ no positive specimen \\
\hline $\begin{array}{l}\text { Lucas et al, } 2019 \\
{[42]}\end{array}$ & IGSR & Police & 76 & Australia & Hands & SEM-EDX & $\begin{array}{l}\text { - } 7.9 \% \text { of the officers returned at least one characteristic PbBaSb particle } \\
\text { - } 75 \% \text { of the officers had at least one consistent particle (in average }<5 \text { ) }\end{array}$ \\
\hline
\end{tabular}




\begin{tabular}{|c|c|c|c|c|c|c|c|}
\hline $\begin{array}{l}\text { Northrop, } 2001 \\
{[15]}\end{array}$ & OGSR & Civilian & 100 & USA & Hands & MEKC & - no positive specimen \\
\hline $\begin{array}{l}\text { Bell and } \\
\text { Seitzinger, } 2016 \\
{[43]}\end{array}$ & OGSR & Civilian & 73 & USA & Hands & IMS & - less than $5 \%$ of positive specimens \\
\hline $\begin{array}{l}\text { Ali et al, } 2016 \\
\text { [44] }\end{array}$ & $\begin{array}{l}\text { IGSR \& } \\
\text { OGSR }\end{array}$ & Police & 70 & USA & Police stations & SEM-EDX \& LC-MS & $\begin{array}{ll} & \text { one characteristic IGSR particle detected (interview desk) } \\
\text { - } & \text { ethylcentralite quantified in two specimens }\end{array}$ \\
\hline $\begin{array}{l}\text { Hofstetter et al, } \\
2017[45]\end{array}$ & OGSR & $\begin{array}{l}\text { Civilian and } \\
\text { police }\end{array}$ & $\begin{array}{l}27 \text { civilians } \\
25 \text { individuals } \\
\text { working in police } \\
\text { laboratory }\end{array}$ & Switzerland & Hands & LC-MS & $\begin{array}{l}\text { - } \\
\text { - } \\
\text { two positive civilian specimen } \\
\text { twive police specimens }\end{array}$ \\
\hline $\begin{array}{l}\text { Manganelli et al, } \\
2019[46]\end{array}$ & OGSR & $\begin{array}{l}\text { Civilian and } \\
\text { police }\end{array}$ & $\begin{array}{l}122 \text { civilians } \\
115 \text { police } \\
\text { officers }\end{array}$ & Switzerland & $\begin{array}{l}\text { Hands and } \\
\text { wrists/sleeves }\end{array}$ & LC-MS & $\begin{array}{l}\text { - } \\
\text { - } \\
\text { - pivilians: } 18 \% \text { of positive hand specimens and } 11.5 \% \text { wrists } / \text { sleeves } \\
\text { policers: } 36.5 \% \text { of positive hand specimens and } 33 \% \text { wrists } / \text { sleeves }\end{array}$ \\
\hline
\end{tabular}


The studies summarized in Table 1 show that prevalence can vary significantly depending on the targeted population. The items/people directly in contact with firearms generally presented the highest prevalence. Occupations involved in police forces or in firearm manufacture generally lead to a higher background than for civilians. Similarly, activities such as hunting or recreational shooting should be taken into account in the evaluation of OGSR evidence. To the best of our knowledge, only two studies have investigated the presence of IGSR $[34,36]$ in police vehicles in North America. Both concluded that the level of contamination was very low (one characteristic $\mathrm{PbBaSb}$ particle detected at most). Another study investigated secondary transfer to volunteers from police vehicles, resulting in two positive specimens, but did not take specimens from the vehicles themselves [44]. The number of studies in vehicles remains very limited and no data regarding OGSR prevalence in police vehicles has been published to date. The aim of the present study was thus to provide data pertaining to the OGSR background levels of police vehicles in Switzerland. Specimens from 64 vehicles were collected from two regional police services and analysed by LC-MS in positive mode. The driver's seat and the back seats were sampled separately to monitor potential differences between locations and to assess the risks of a suspect being contaminated by OGSR during transportation to a police station.

\section{MATERIALS AND METHODS}

\subsection{Specimen collection and preparation}

Specimens were collected from 64 police vehicles in collaboration with two regional police services. Collection was performed using carbon stubs from Plano (Wetzlar, Germany), consisting of an adhesive carbon tab $12 \mathrm{~mm}$ in diameter mounted on a $12.5 \mathrm{~mm}$ aluminium inserted in a plastic vial and sealed with a screw cap. Two stubs were collected per vehicle: the first one from the driver's seat and the second from the back seats. The stubs were dabbed about 200 times on the seats (the whole surface was sampled), following recommendations from Zeichner et al. [47] for clothing items.

For compound extraction, the carbon adhesive was removed from the stub with clean tweezers and transferred to a $20 \mathrm{~mL}$ scintillation vial containing $1 \mathrm{~mL} \mathrm{MeOH}$. The vial was placed in an ultrasonic bath at room temperature for 15 minutes before filtration of the resulting extract through a $0.2 \mu \mathrm{m}$ Chromafil PTFE syringe filter (Macherey-Nagel, Düren, Germany) to remove carbon particles. To detect potential laboratory contamination during specimen preparation, methanol blanks were prepared before and after each extraction session. Likewise, a blank carbon tab was extracted to check for potential contamination originating from the stub batch. For all these control samples, no OGSR were detected. 


\subsection{Chemicals}

117 Acetonitrile, methanol, formic acid (FA) and water were of ULC/MS grade (Biosolve, France). The 118 study targeted seven OGSR compounds: diphenylamine (DPA) from Fluka (Buchs, Switzerland); ethylcentralite (EC), $N$-nitrosodiphenylamine ( $N$-nDPA), 4-nitrodiphenylamine (4-nDPA), akardite II (AK II) from Sigma-Aldrich (Buchs, Switzerland); 2-nitrodiphenylamine (2-nDPA) from Alfa Aesar (Karlsruhe, Germany); methylcentralite (MC) from MP Biomedicals (Illkirch, France). Standard solutions at $1 \mathrm{mg} / \mathrm{mL}$ were prepared in $\mathrm{MeOH}$ and stored at $4^{\circ} \mathrm{C}$.

\subsection{Instrumentation}

The specimens were analysed using an Exion ultra-high performance liquid chromatography (UHPLC) coupled to a QTrap 6500 from AB Sciex. The UHPLC instrument was equipped with a binary pump enabling a maximum delivery flow rate of $10 \mathrm{~mL} / \mathrm{min}$, an autosampler, and a thermostatically-controlled column compartment. Separation was obtained using a C18 Kinetex core-shell column (Phenomenex). A C18 pre-column cartridge (SecurityGuard ULTRA) was placed before the analytical column for protection. All UHPLC parameters are described in Table 2.

Table 2. UHPLC parameters

\begin{tabular}{|c|c|c|c|}
\hline \multicolumn{4}{|l|}{ UHPLC parameters } \\
\hline Column type & \multicolumn{3}{|c|}{$\mathrm{C} 18(2.6 \mu \mathrm{m}, 2.1 \mathrm{~mm} \times 100 \mathrm{~mm})$} \\
\hline Column temperature & \multicolumn{3}{|l|}{$40{ }^{\circ} \mathrm{C}$} \\
\hline Flow rate & \multicolumn{3}{|c|}{$0.4 \mathrm{~mL} / \mathrm{min}$} \\
\hline Injection volume & \multicolumn{3}{|c|}{$5 \mu \mathrm{L}$} \\
\hline \multirow[t]{9}{*}{ Gradient table } & $\mathrm{t} / \mathrm{min}$ & $\% \mathrm{~A}$ & $\% \mathrm{~B}$ \\
\hline & & $\mathrm{H}_{2} \mathrm{O}+0.1 \% \mathrm{FA}$ & $A C N+0.1 \% F A$ \\
\hline & 0 & 65 & 35 \\
\hline & 0.5 & 65 & 35 \\
\hline & 4 & 40 & 60 \\
\hline & 4.5 & 0 & 100 \\
\hline & 5 & 0 & 100 \\
\hline & 5.5 & 65 & 35 \\
\hline & 7 & 65 & 35 \\
\hline
\end{tabular}

Electrospray ionization was operated in positive mode. For all target compounds, the ion $[\mathrm{M}+\mathrm{H}]^{+}$was defined as the precursor ion and quantification was obtained from the SRM measurements (Table 3). The source parameters were the following: the desolvation temperature (TEM) was set to $400^{\circ} \mathrm{C}$, the nebulizer gas to $65 \mathrm{psig}$, the turbo gas to $65 \mathrm{psig}$, the curtain gas to $30 \mathrm{psig}$ and the IonSpray voltage to 5000 V. Data acquisition and instrument control were monitored using Analyst ${ }^{\circledR}$ software (version 1.6.3). Data treatment and quantitation were performed using MultiQuant ${ }^{\circledR}$ software (version 3.0.2). Semi-quantitative data were obtained from a calibration curve (10 levels, 2 replicates) measured for each 

(2-nDPA, 4-nDPA and AK II), $40 \mathrm{ng} / \mathrm{mL}$ ( $N$-nDPA) and $100 \mathrm{ng} / \mathrm{mL}$ (DPA).

143 Table 3: MS parameters

\begin{tabular}{|c|c|c|c|c|c|}
\hline Target compounds & SRM transitions & LOD [ng/mL] & $\begin{array}{l}\text { Declustering } \\
\text { potential }[\mathrm{V}]\end{array}$ & $\begin{array}{l}\text { Collision energy } \\
{[\mathrm{V}]}\end{array}$ & $\begin{array}{l}\text { Collision cell } \\
\text { exit potential } \\
{[\mathrm{V}]}\end{array}$ \\
\hline Diphenylamine (DPA) & $\begin{array}{l}170.1 \rightarrow 93.0 \\
170.1 \rightarrow 152.0\end{array}$ & 0.2 & $\begin{array}{l}51 \\
71\end{array}$ & $\begin{array}{l}31 \\
37\end{array}$ & $\begin{array}{l}10 \\
4\end{array}$ \\
\hline $\begin{array}{l}N \text {-nitrosodiphenylamine } \\
(N \text {-nDPA) }\end{array}$ & $\begin{array}{l}199.0 \rightarrow 169.0 \\
199.0 \rightarrow 66.0\end{array}$ & 0.02 & $\begin{array}{l}30 \\
30\end{array}$ & $\begin{array}{l}15 \\
29\end{array}$ & $\begin{array}{l}20 \\
8\end{array}$ \\
\hline $\begin{array}{l}\text { 2-nitrodiphenylamine (2- } \\
\text { nDPA) }\end{array}$ & $\begin{array}{l}215.0 \rightarrow 180.0 \\
215.0 \rightarrow 198.0\end{array}$ & 0.02 & $\begin{array}{l}60 \\
60\end{array}$ & $\begin{array}{l}23 \\
19\end{array}$ & $\begin{array}{l}20 \\
20\end{array}$ \\
\hline $\begin{array}{l}\text { 4-nitrodiphenylamine (4- } \\
\text { nDPA) }\end{array}$ & $\begin{array}{l}215.0 \rightarrow 198.0 \\
215.0 \rightarrow 167.0\end{array}$ & 0.05 & $\begin{array}{l}60 \\
60\end{array}$ & $\begin{array}{l}19 \\
45\end{array}$ & $\begin{array}{l}20 \\
18\end{array}$ \\
\hline Ethylcentralite (EC) & $\begin{array}{l}269.1 \rightarrow 148.0 \\
269.1 \rightarrow 120.0\end{array}$ & 0.005 & $\begin{array}{l}80 \\
80\end{array}$ & $\begin{array}{l}19 \\
29\end{array}$ & $\begin{array}{l}16 \\
14\end{array}$ \\
\hline Methylcentralite (MC) & $\begin{array}{l}241.1 \rightarrow 134.0 \\
241.1 \rightarrow 106.0\end{array}$ & 0.005 & $\begin{array}{l}60 \\
60\end{array}$ & $\begin{array}{l}20 \\
33\end{array}$ & $\begin{array}{l}16 \\
14\end{array}$ \\
\hline Akardite II (AK II) & $\begin{aligned} 227.0 & \rightarrow 170.2 \\
227.0 & \rightarrow 91.9\end{aligned}$ & 0.005 & $\begin{array}{l}80 \\
80\end{array}$ & $\begin{array}{l}23 \\
35\end{array}$ & $\begin{array}{l}20 \\
15\end{array}$ \\
\hline
\end{tabular}

144

\section{RESULTS AND DISCUSSION}

The police vehicle population involved 64 vehicles, 31 from one regional police service and 33 from another. The vehicles had various functions: part were used by patrols for road surveillance or other community policing activities (Gendarmerie), others by the "Police de Sûreté", and some for group and/or prisoner transportation. In the "Gendarmerie" whose main mission is to maintain security and order, the officers wear uniforms and generally drive marked police vehicles. The "Police de Sûreté" is mainly involved in investigations of crimes and officers are in civilian clothes. These officers generally travel in unmarked police cars. "Gendarmerie" vehicles often contain firearms that are permanently present within the vehicle and are rarely used in practice. The driver's seat was targeted to evaluate the extent of secondary transfer from police officers. The back seat was sampled as well as it is used for suspect transportation and could be a contamination source. Data was collected regarding the permanent presence of one or more firearms and their location(s) within the vehicle, and whenever available the frequency of passenger compartment cleaning.

The results showed that most of the 64 vehicles were uncontaminated (44 driver's seats and 38 back seats respectively, see Figure 1). Interestingly, the back seats (26 vehicles) were slightly more contaminated than the driver's seats (20 vehicles). The number of compounds detected simultaneously was up to six out of the seven targeted, detected once on a driver's seat and twice on back seats. As a general trend, increased numbers of compounds detected simultaneously exhibited lower detection frequencies. Thus, based on these data, the combined presence of four or more compounds in a police 
vehicle seat appears to be a relatively rare occurrence, as only nine cars presented such results ( 3 of them both on the driver's and back seats).

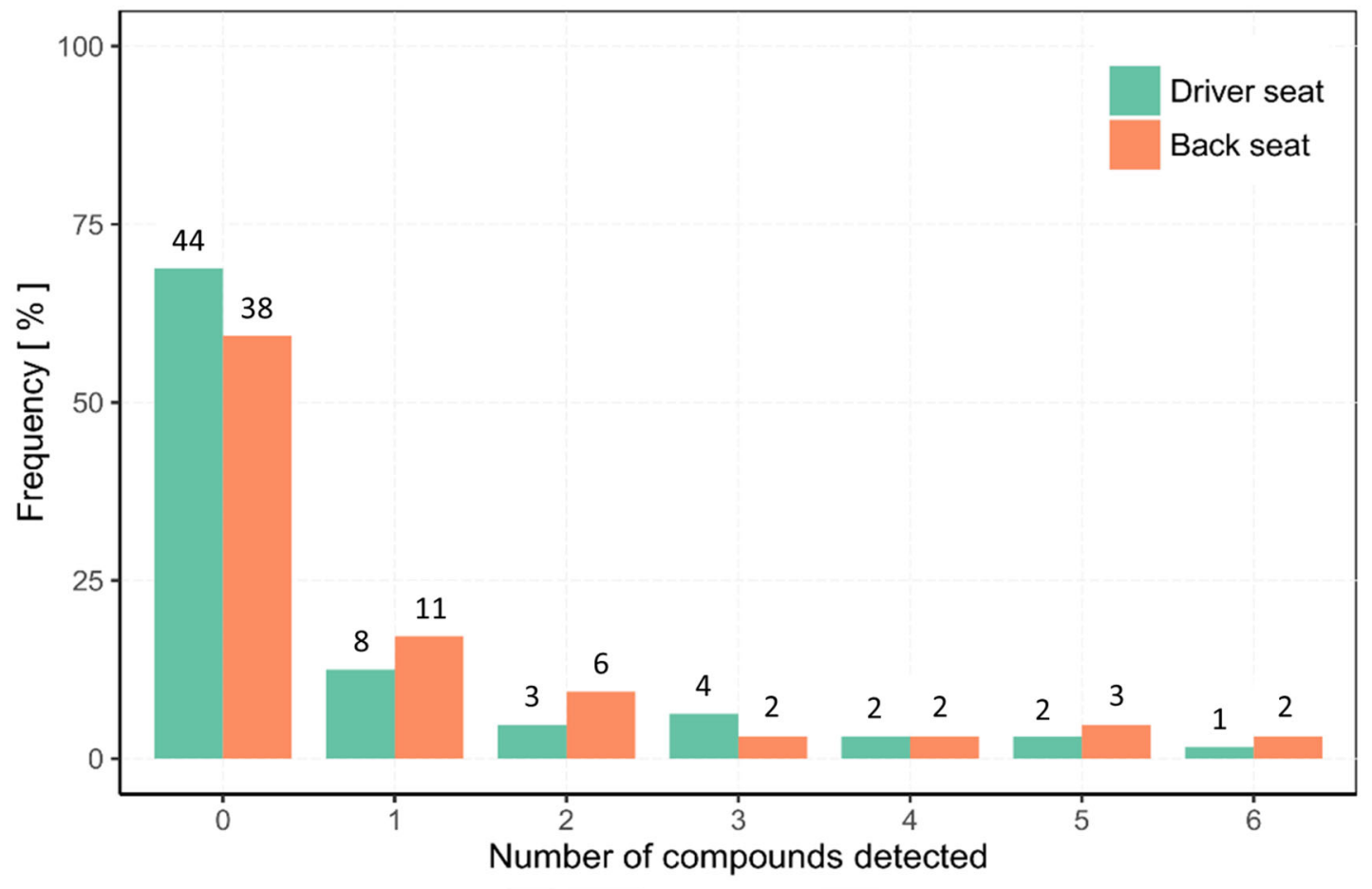

Figure 1: Prevalence versus number of compounds detected in police vehicles $(n=64)$. The numbers of cars in each category are indicated above the histogram bars.

As the samples were collected from two regional police services, the data was separated according to its origin to investigate potential differences (Figure 2). It can be observed that the OGSR background level varied slightly between the two services. OGSR were detected in more cars from police service 1 (42.4\% and $60.6 \%$ for the driver and back seat respectively) than in cars from police service $2(19.4 \%$ for both driver and back seats). These results might be explained by three factors: the presence and location of permanent firearms within the vehicle; the cleaning frequency; and the random sampling of cars available at the time of specimen collection. In police service 1, the firearms (submachine guns) were laid, covered by a blanket, over the back seat and/or in the trunk, whereas in police service 2, the guns were stored in a box fastened to the car door or in a box attached to the rear of the back seat in the trunk. The process of storing firearms in boxes might minimize seat contamination, as GSR might be deposited inside the box instead of the seat. Such an explanation applies only to back seat contamination and should not influence background levels on the driver's seat. One factor potentially influencing background levels on both front and back seats is the cleaning frequency. Unfortunately, information regarding cleaning frequency could not be obtained for all cars. For eleven cars in police service 1, the last cleaning occurred five weeks before specimen collection, for one car three days and for another one the day before. However, for the second service, marked police cars (representing about half of the sampled vehicles) are cleaned (inside as well as outside) on a daily basis. For the unmarked cars, this 
information could not be obtained. Interestingly, in police service 2, the unmarked cars had less OGSR background (two out of 17 cars with only one compound detected) than the marked cars that were cleaned on a daily basis (six out of 13). Major differences between those cars were their use by uniformed police officers, carrying a visible service weapon and the presence of guns within the car (marked cars) versus plainclothes police officers, carrying a concealed service weapon and the absence of other firearms within the vehicle. Such trend was not observed for police service 1 as the background levels were similar for marked and unmarked cars. However, it remains difficult to identify the real cause of the observed differences, as the limited number of cars sampled might not be representative of the whole vehicle population.
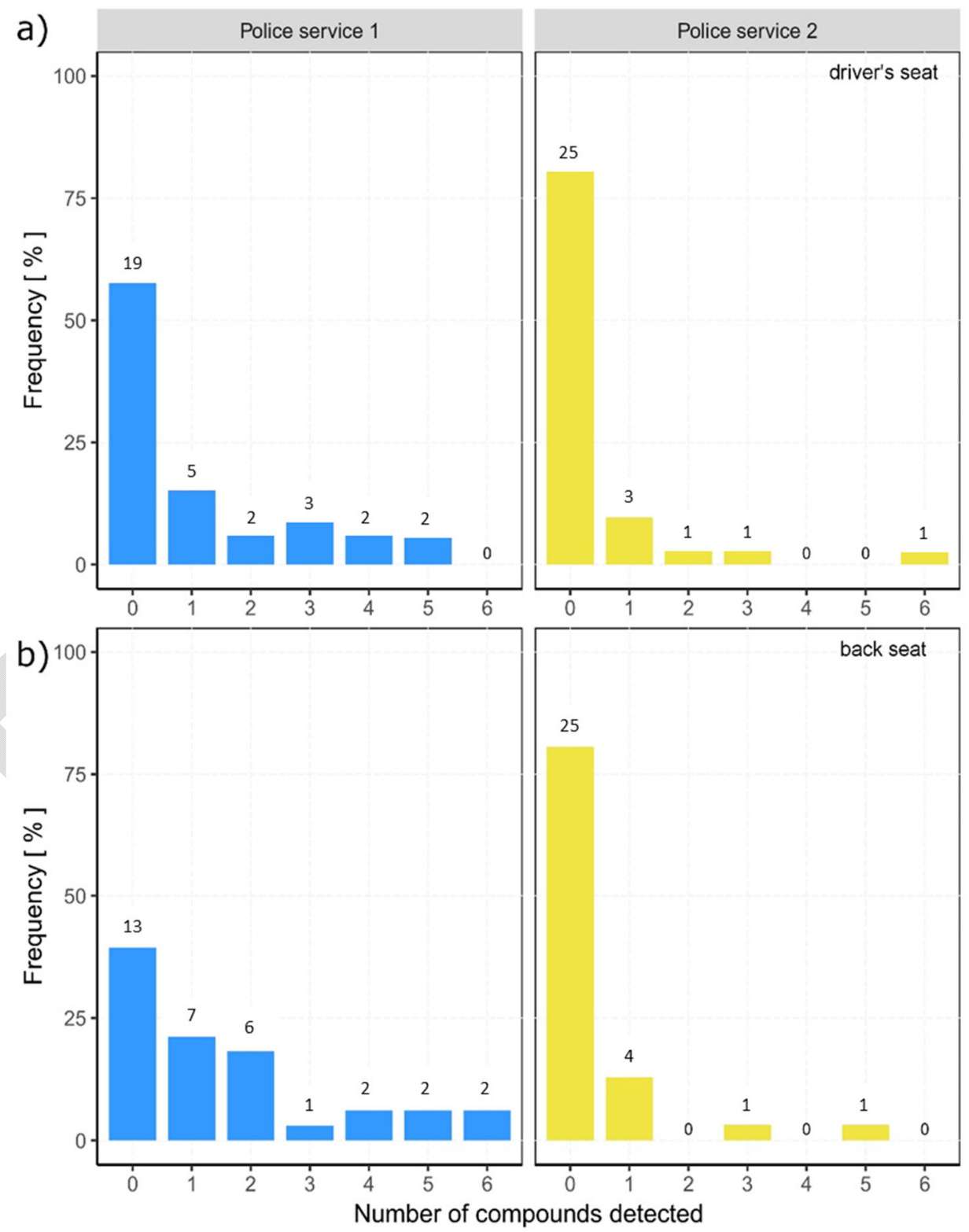

Figure 2: Prevalence versus number of compounds detected on the a) driver seat, b) back seat of police vehicles as a function of police service $\left(\mathrm{n}_{1}=33, \mathrm{n}_{2}=31\right)$. The numbers of cars in each category are indicated above the histogram bars. 
As to the number of times a specific OGSR compound was observed (Figure 3), EC was the most frequently encountered in the sampled vehicles $(20 \%$ and $26.6 \%$ of all cars for the driver and back seats, respectively). AK II, DPA and $N$-nDPA followed with percentages between 9 and 20\%. The DPA derivatives, 2-nDPA and 4-nDPA were slightly less frequently detected than DPA and $N$-nDPA. It is interesting to note that $\mathrm{MC}$ was only detected once. This might indicate that the propellant used by these police services in shooting training sessions or in duty does not contain this compound. No significant differences were observed in the occurrence of compounds between the two services.

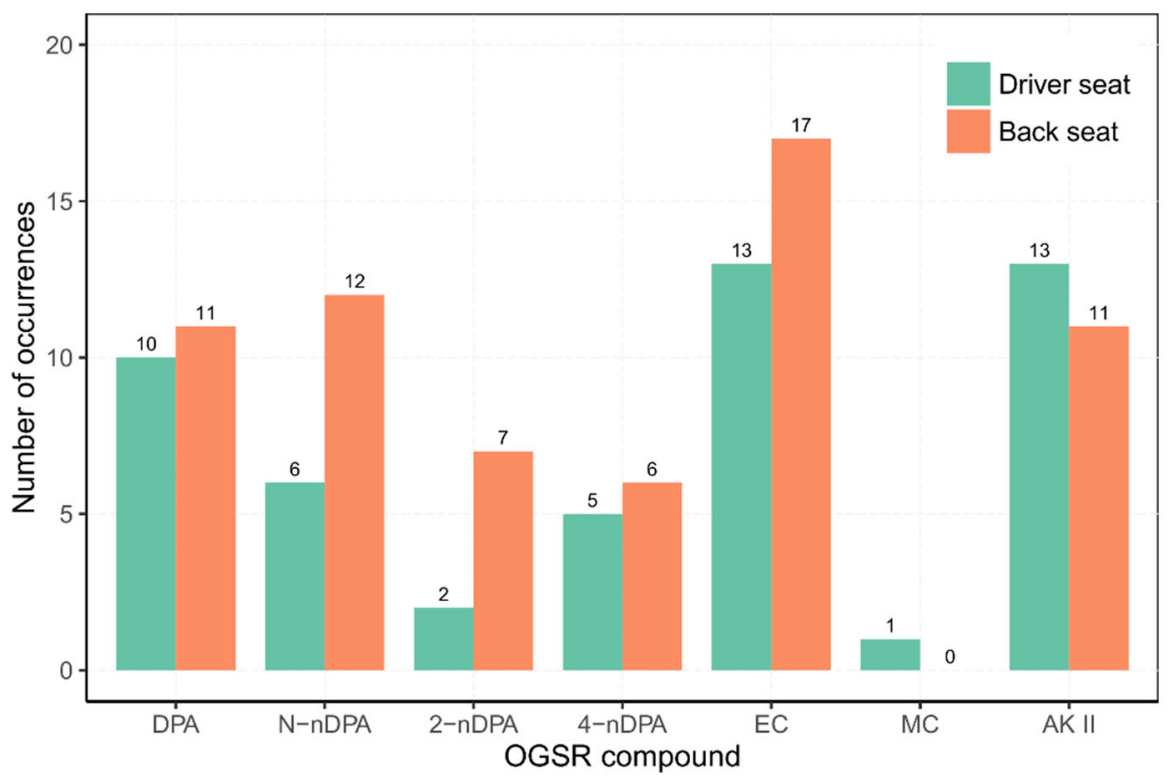
Figure 3: Number of occurrences versus compound in police vehicles $(n=64)$

A recent study investigated OGSR prevalence on the hands and wrists/sleeves of police officers from three Swiss police services [46]. It indicated that $N$-nDPA and EC were the most frequently detected compounds (29.6\% and $21.7 \%$ on hands for $N$-nDPA and EC respectively), closely followed by DPA plus derivatives and AK II. MC was also only detected once. In spite of the different percentages, the results between both studies regarding the type of compounds detected are in good agreement. Thus, the OGSR compounds detected in police vehicles are most certainly transferred from police officers and firearms through secondary transfer. Nevertheless, an environmental source cannot be totally excluded when for example only one compound is detected. A background study involving new vehicles could provide information on the environmental presence of these compounds on car seats. However, the absence of OGSR compounds in most of the police vehicles tends to indicate that these compounds are not normally present on car seats.

The amounts detected in the specimens (Figure 4) were in the low and sub-nanogram range, except for two specimens at $12.3 \mathrm{ng} / \mathrm{mL}$ (DPA) and $8.16 \mathrm{ng} / \mathrm{mL}(N-\mathrm{nDPA})$. It is interesting to see that the highest values were for DPA and $N$-nDPA, while the other compounds were all detected below $1 \mathrm{ng} / \mathrm{mL}$. There were no significant differences between the amounts detected on the driver's and back seats. The results 
of Figure 4 were represented as boxplots, but only outliers were observed, as the values for the medians, the first and third quartiles were all equal to zero. This highlights the low number of cars positive to OGSR and the very low amounts detected, thus indicating that detecting a specific compound happened in less than $25 \%$ of the specimens. Compared to amounts that are detected on the hands of shooters just after discharge or to the prevalence study of police officers involving sampling just after shooting training (highest values above $100 \mathrm{ng}$ ), the amounts detected in vehicles are much lower.

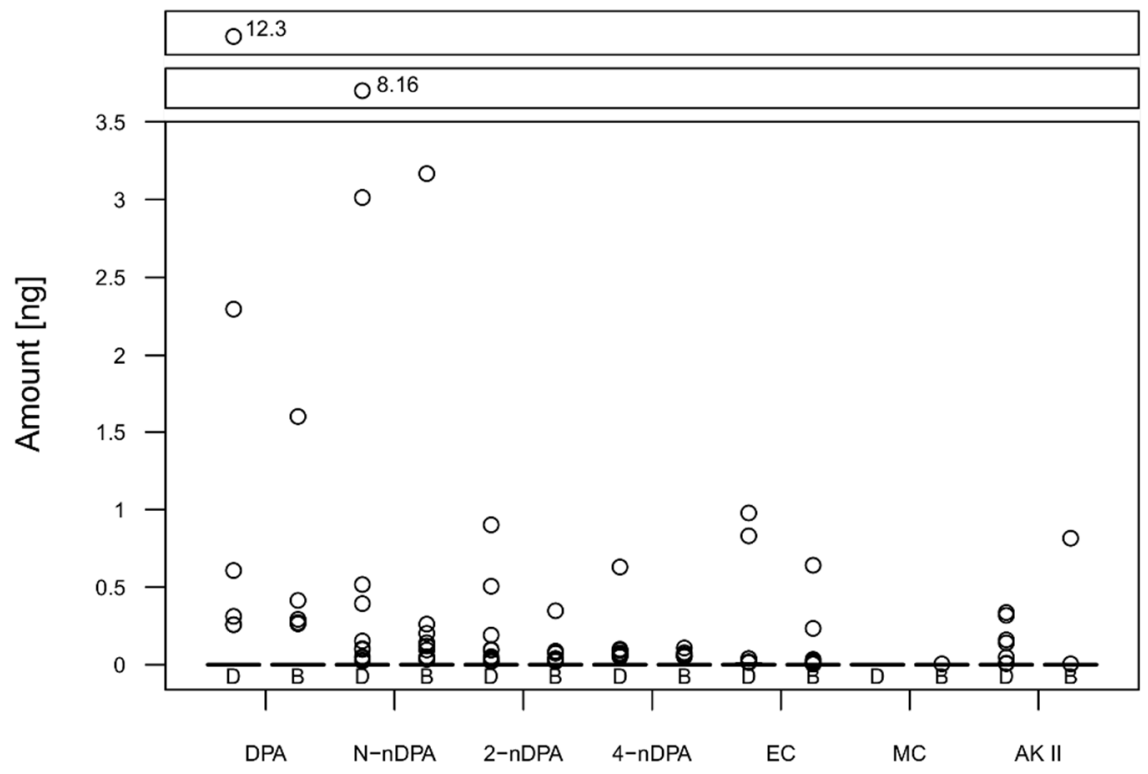

Figure 4: Prevalence in the police vehicle population: Amount of analyte detected. The letters D and B denote the driver and back seat respectively $(n=64)$

The specimens with the highest compound numbers (five and six) were investigated in greater depth in order to explain the background level and to qualitatively evaluate if there was a correlation between the number of compounds and the amount detected on both seats. In total, six vehicles had five or six compounds detected on either the driver or the back seat (Table 4). While in four vehicles, contamination was present on both seats, it was not the case for two cars. In vehicles 20 and 29, no OGSR was detected on the driver's seat, whereas six and five compounds were detected on the back seat respectively. Thus, detecting a high number of compounds on the back seat was not indicative of similar contamination of the driver's seat. It is thus reasonable to assume that contamination of driver and back seats is not necessarily correlated and that secondary transfer may occur independently from two separate sources. 
Table 4: summary of the results from the six police vehicles with the highest background level

\begin{tabular}{|c|c|c|c|c|}
\hline \multirow[t]{2}{*}{ Car } & \multicolumn{2}{|c|}{ Driver seat OGSR } & \multicolumn{2}{|c|}{ Back seat OGSR nb } \\
\hline & Number of compounds & Compounds detected & Number of compounds & Compounds detected \\
\hline Car 16 & 5 & $\begin{array}{c}N \text {-nDPA, 4-nDPA, 2-nDPA, } \\
\text { AK II, EC }\end{array}$ & 4 & $\begin{array}{c}N \text {-nDPA, 2-nDPA, AK II, } \\
\text { EC }\end{array}$ \\
\hline Car 20 & 0 & - & 6 & $\begin{array}{c}\text { DPA, } N \text {-nDPA, 4-nDPA, } \\
\text { 2-nDPA, AK II, EC }\end{array}$ \\
\hline Car 26 & 2 & $N$-nDPA, EC & 6 & $\begin{array}{c}\text { DPA, } N \text {-nDPA, 4-nDPA, } \\
\text { 2-nDPA, AK II, EC }\end{array}$ \\
\hline Car 29 & 0 & - & 5 & $\begin{array}{c}\text { DPA, } N \text {-nDPA, 4-nDPA, } \\
\text { 2-nDPA, EC }\end{array}$ \\
\hline Car 33 & 5 & $\begin{array}{c}\text { DPA, } N \text {-nDPA, 4-nDPA, } \\
\text { 2-nDPA, EC }\end{array}$ & 5 & $\begin{array}{c}\text { DPA, } N \text {-nDPA, 2-nDPA, } \\
\text { AK II, EC }\end{array}$ \\
\hline Car 4 & 6 & $\begin{array}{c}\text { DPA, } N \text {-nDPA, 4-nDPA, } \\
\text { 2-nDPA, AK II, EC }\end{array}$ & & $\begin{array}{c}\text { DPA, } N \text {-nDPA, 4-nDPA, } \\
\text { 2-nDPA, EC }\end{array}$ \\
\hline
\end{tabular}

253

254

255

256

257

258

259

260

261

262

263

264

265

266

267

For car 16, a police officer had used the vehicle to go to a shooting session two months before specimen collection. There was no firearm present permanently in the car. No information regarding the last cleaning was available. Contamination through secondary transfer from the shooting police officer might be a valid hypothesis as OGSR persistence is expected to be longer on car seats compared with hands. However, no data is currently available and the persistence of such contamination should be investigated. For car 20, no firearm was stored in the vehicle, but it was used to drive groups of police officers to courses or shooting sessions, which might explain the presence of OGSR on the back seats. No information regarding last cleaning could be obtained. For car 29, a submachine gun was present on the back seat, but no information could be obtained regarding its recent use or manipulation. Contact with the submachine gun might be an explanation for that contamination. For car 4, a gun was stored in a box fastened to a door and the car was theoretically cleaned in the last 24 hours, so it is more difficult to find an explanation for this background. Can a contamination persist in spite of the cleaning or was it contaminated after the cleaning? It must be highlighted that for each compound, car 4 had the highest values detected in the study. For cars 26 and 33, no firearm was present in the car, no information regarding last cleaning was available and no concrete explanation could be found. In all cases, vehicles were used by police officers carrying firearms and these might be a source of contamination, even though the present results indicate that it is a relatively rare occurrence.

In terms of degree of contamination, the scenario producing the highest amounts and numbers of OGSR on car seats would probably be the discharge of a firearm within the vehicle. That would represent a primary transfer scenario. The use of a firearm on duty is anecdotal in Switzerland. The discharge of a firearm within a police vehicle would be even rarer. No data regarding the amounts to be expected in such an instance was found in the literature and it would be interesting to perform some experiments to assess the degree of contamination that can result from a discharge within a vehicle. Experiments 
performed by Burnett and Lebiedzik for IGSR showed heavy contamination of interior surfaces such as the dashboard or the window frame when a firearm was discharged by the driver of a vehicle through an opened window [32]. Secondary transfer scenarios would most probably lead to lower background levels than primary transfer scenarios as evidenced by some studies regarding secondary transfer from a shooter or a firearm to a third party $[29,30]$. The most common hypotheses would then be secondary transfer from contaminated police officers or from firearms that are either present or manipulated in the vehicle. The background level of police vehicles might also be influenced by factors such as the car cleaning frequency, the number of users and frequency of use. One might expect a higher OGSR contamination if a vehicle is used to go to a shooting training than during normal duty. The same line of reasoning holds for the number of users, as the probability of secondary transfer might increase with that number. Logically, the more frequently a car is used, the higher the probability of secondary transfer from the various users. However, it is also possible that the persistence of OGSR might decrease when the number of users and the frequency of the vehicle use increases. Such parameters might be interesting study perspectives.

Other OGSR prevalence studies involving cars could not be found in the literature. However, two studies investigated the presence of IGSR in police vehicles. Berk et al. found one PbBaSb particle in two vehicles [34] and Gerard et al. found one PbBaSb particle in two of the 18 vehicles sampled [36]. Both studies concluded that the risk of secondary transfer from police vehicles was low, even though possible. The present study for OGSR showed that most of the police vehicles sampled were free from OGSR. However, up to six compounds were detected simultaneously in a number of vehicles in amounts up to $10 \mathrm{ng}$. As a precaution, suspect transportation should be performed in cars not used by heavily contaminated users or within which a firearm is present or was manipulated. Another recommendation would be the regular cleaning (vacuuming) of the vehicle's interior surfaces with a monitoring of the efficiency of the procedure on removal of GSR in general. Experiments involving the transportation of individuals in police vehicles would provide data as to the real risk of OGSR tertiary transfer from the seats to an individual transported in such vehicle.

\section{CONCLUSIONS}

The present study aimed at evaluating the OGSR background level in police vehicles. Specimens from the driver and back seats were separately collected from 64 cars from two regional police services in Switzerland. The results showed that most of the 64 vehicles were uncontaminated (44 driver seats and 38 back seats respectively). The number of compounds detected on a single seat was up to six compounds, detected once on a driver and twice on back seats. A trend was observed, as the contamination frequency decreased with the number of compounds detected together. The amounts detected were in the low ng range and inferior to amounts generally detected just after discharge on a 
shooter. Our data indicate that detecting a combination of four or more compounds on a police vehicle seat appears to be a relatively rare occurrence.

In the light of the anecdotal firearm use on duty in Switzerland, it seems logical that the background contamination observed is due to secondary transfer from police officers (for example contaminated through recent participation to a shooting session or firearm manipulation) or from firearms stored in the vehicles. Thus, the background might be different in other countries in which firearms are more often used on duty (in a car chase for example). The present results might be used as a recommendation to minimize contact of a suspect with contaminated surfaces if OGSR is implemented in routine work in parallel to IGSR analysis. Therefore, regular cleaning of police vehicles' interior surfaces and monitoring of the GSR background of cars usually used for suspect transportation should be performed. Moreover, to help interpretation of the GSR evidence, a specimen from the vehicle might also be collected before suspect transportation as a blank to evaluate risks of secondary transfer from the police car back seats. Another option would be to protect the hands of the suspect by plastic bags. However, that would not exclude potential contamination from the car seats to the suspect's clothing for example.

\section{Acknowledgements}

The authors wish to acknowledge the Swiss National Science Foundation (10521A_165608) for financial support. They also would like to thank two Swiss police services for enabling the collection of the vehicle prevalence specimens, especially Commissaire Nicola Albertini, Adjudant Jean-Philippe Jaquier, Inspecteur Arnaud Yersin from the Police Cantonale Vaudoise, Adjudant Dr Balthasar Jung, Sergeant Manuela Manganelli from the Kantonspolizei Aargau. They are grateful to Dr Amanda Frick for proof reading this manuscript, to Virginie Redouté Minzière for helping with part of the specimen collection process and to Dr Ana Moraleda Merlo for preparation of the calibration standards.

\section{Bibliography}

[1] Zeichner A. Recent developments in methods of chemical analysis in investigations of firearm-related events. Anal Bioanal Chem. 2003;376:1178-91.

[2] Wallace JS. Chemical Analysis of Firearms, Ammunition, and Gunshot Residue. Boca Raton: CRC Press; 2008.

[3] Wolten GM, Nesbitt RS, Calloway AR, Loper GL, Jones PF. Equipment Systems Improvement Program: Final Report on Particle Analysis for Gunshot Residue Detection. Law Enforcement Development Group. USA: The Aerospace Corporation; 1977.

[4] Zeichner A. Firearm Discharge Residue: Analysis of. In: John Wiley \& Sons L, editor. Wiley Encyclopedia of Forensic Science2009.

[5] Meng HH, Caddy B. Gunshot residue analysis - A review. J Forensic Sci. 1997;42:553-70.

[6] Dalby O, Butler D, Birkett JW. Analysis of Gunshot Residue and Associated Materials-A Review. J Forensic Sci. 2010;55:924-43.

[7] Lopez-Lopez M, Delgado JJ, Garcia-Ruiz C. Ammunition Identification by Means of the Organic Analysis of Gunshot Residues Using Raman Spectroscopy. Anal Chem. 2012;84:3581-5.

[8] Abrego Z, Grijalba N, Unceta N, Maguregui M, Sanchez A, Fernandez-Isla A, et al. A novel method for the identification of inorganic and organic gunshot residue particles of lead-free ammunitions from the hands of shooters using scanning laser ablation-ICPMS and Raman micro-spectroscopy. Analyst. 2014;139:6232-41. 
[9] Bueno J, Lednev IK. Raman microspectroscopic chemical mapping and chemometric classification for the identification of gunshot residue on adhesive tape. Anal Bioanal Chem. 2014;406:4595-9. [10] Bueno J, Sikirzhytski V, Lednev IK. Attenuated Total Reflectance-FT-IR Spectroscopy for Gunshot Residue Analysis: Potential for Ammunition Determination. Anal Chem. 2013;85:7287-94.

[11] Bueno J, Lednev IK. Attenuated Total Reflectance-FT-IR Imaging for Rapid and Automated Detection of Gunshot Residue. Anal Chem. 2014;86:3389-96.

[12] Arndt J, Bell S, Crookshanks L, Lovejoy M, Oleska C, Tulley T, et al. Preliminary evaluation of the persistence of organic gunshot residue. Forensic Sci Int. 2012;222:137-45. [13] Moran JW, Bell S. Skin Permeation of Organic Gunshot Residue: Implications for Sampling and Analysis. Anal Chem. 2014;86:6071-9.

[14] Yeager B, Bustin K, Stewart J, Dross R, Bell S. Evaluation and validation of ion mobility spectrometry for presumptive testing targeting the organic constituents of firearms discharge residue. Anal Methods-Uk. 2015;7:9683-91.

[15] Northrop DM. Gunshot residue analysis by micellar electrokinetic capillary electrophoresis: Assessment for application to casework. Part I. J Forensic Sci. 2001;46:549-59.

[16] Northrop DM. Gunshot residue analysis by micellar electrokinetic capillary electrophoresis: Assessment for application to casework. Part II. J Forensic Sci. 2001;46:560-72.

[17] Reardon MR, MacCrehan WA, Rowe WF. Comparing the additive composition of smokeless gunpowder and its handgun-fired residues. J Forensic Sci. 2000;45:1232-8.

[18] MacCrehan WA, Patierno ER, Duewer DL, Reardon MR. Investigating the effect of changing ammunition on the composition of organic additives in gunshot residue (OGSR). J Forensic Sci. 2001;46:57-62.

[19] Muller D, Levy A, Vinokurov A, Ravreby M, Shelef R, Wolf E, et al. A novel method for the analysis of discharged smokeless powder residues. J Forensic Sci. 2007;52:75-8.

[20] Zeichner A, Eldar B. A novel method for extraction and analysis of gunpowder residues on double-side adhesive coated stubs. J Forensic Sci. 2004;49:1194-206.

[21] Tarifa A, Almirall JR. Fast detection and characterization of organic and inorganic gunshot residues on the hands of suspects by CMV-GC-MS and LIBS. Sci Justice. 2015;55:168-75.

[22] Laza D, Nys B, De Kinder J, Mesmaeker AKD, Moucheron C. Development of a quantitative LC-MS/MS method for the analysis of common propellant powder stabilizers in gunshot residue. J Forensic Sci. 2007;52:84250 .

[23] Thomas JL, Lincoln D, McCord BR. Separation and Detection of Smokeless Powder Additives by Ultra Performance Liquid Chromatography with Tandem Mass Spectrometry (UPLC/MS/MS). J Forensic Sci. 2013;58:609-15.

[24] Benito S, Abrego Z, Sanchez A, Unceta N, Goicolea MA, Barrio RJ. Characterization of organic gunshot residues in lead-free ammunition using a new sample collection device for liquid chromatography-quadrupole time-of-flight mass spectrometry. Forensic Sci Int. 2015;246:79-85.

[25] Taudte RV, Roux C, Blanes L, Horder M, Kirkbride KP, Beavis A. The development and comparison of collection techniques for inorganic and organic gunshot residues. Anal Bioanal Chem. 2016;408:2567-76.

[26] Gassner AL, Weyermann C. LC-MS method development and comparison of sampling materials for the analysis of organic gunshot residues. Forensic Sci Int. 2016;264:47-55.

[27] BKA. Development of analytical methods for sensitive detection and identification of organic gunshot residues (OGSR) based on liquid chromatography-mass spectrometry (LC-MS) for routine casework. 2017.

[28] Maitre M, Horder M, Kirkbride KP, Gassner AL, Weyermann C, Roux C, et al. A forensic investigation on the persistence of organic gunshot residues. Forensic Sci Int. 2018;292:1-10.

[29] Gassner AL, Manganelli M, Werner D, Rhumorbarbe D, Maitre M, Beavis A, et al. Secondary transfer of organic gunshot residues: Empirical data to assist the evaluation of three scenarios. Sci Justice. 2019;59:58-66.

[30] Maitre M, Chadwick S, Kirkbride PK, Gassner AL, Weyermann C, Beavis A, et al. An investigation on the secondary transfer of organic gunshot residues. Sci Justice. 2019; In Press.

[31] Romolo FS, Margot P. Identification of gunshot residue: a critical review. Forensic Sci Int. 2001;119:195211 .

[32] Burnett BR, Lebiedzik J. Discharge of a Pistol Out a Car Window with the Breech Within the Interior of the Car: Analysis of Gunshot Residue on a Car's Interior Surfaces. J Forensic Sci. 2017;62:768-72.

[33] Gialamas DM, Rhodes EF, Sugarman LA. Officers, Their Weapons and Their Hands - an Empirical-Study of Gsr on the Hands of Non-Shooting Police Officers. J Forensic Sci. 1995;40:1086-9.

[34] Berk RE, Rochowicz SA, Wong M, Kopina MA. Gunshot residue in Chicago police vehicles and facilities: An empirical study. J Forensic Sci. 2007;52:838-41.

[35] Lindsay E, McVicar MJ, Robert V. Gerard RV, Randall ED. Observations of GSR on the Hands of Employees at Firearms Manufacturing Facilities. Canadian Society of Forensic Science Journal. 2011;44:105-9. 
[36] Gerard RV, Lindsay E, McVicar MJ, Randall ED, Gapinska A. Observations of Gunshot Residue Associated with Police Officers, Their Equipment, and Their Vehicles. Canadian Society of Forensic Science Journal. 2012;45:57-63.

[37] Brozek-Mucha Z. On the prevalence of gunshot residue in selected populations - An empirical study performed with SEM-EDX analysis. Forensic Sci Int. 2014;237:46-52.

[38] Hannigan TJ, McDermott SD, Greaney CM, O'Shaughnessy J, O'Brien CM. Evaluation of gunshot residue (GSR) evidence: Surveys of prevalence of GSR on clothing and frequency of residue types. Forensic Sci Int. 2015;257:177-81.

[39] Cook M. Gunshot residue contamination of the hands of police officers following start-of-shift handling of their firearm. Forensic Sci Int. 2016;269:56-62.

[40] Lucas N, Brown H, Cook M, Redman K, Condon T, Wrobel H, et al. A study into the distribution of gunshot residue particles in the random population. Forensic Sci Int. 2016;262:150-5.

[41] Comanescu MA, Millett TJ, Kubic TA. A Study of Background Levels of Antimony, Barium, and Lead on Vehicle Surface Samples by Graphite Furnace Atomic Absorption. J Forensic Sci. 2019;64:565-9.

[42] Lucas N, Cook M, Kirkbride KP, Kobus H. Gunshot residue background on police officers: Considerations for secondary transfer in GSR evidence evaluation. Forensic Sci Int. 2019;297:293-301.

[43] Bell S, Seitzinger L. From binary presumptive assays to probabilistic assessments: Differentiation of shooters from non-shooters using IMS, OGSR, neural networks, and likelihood ratios. Forensic Sci Int. 2016;263:176-85.

[44] Ali L, Brown K, Castellano H, Wetzel SJ. A Study of the Presence of Gunshot Residue in Pittsburgh Police Stations using SEM/EDS and LC-MS/MS. J Forensic Sci. 2016;61:928-38.

[45] Hofstetter C, Maitre M, Beavis A, Roux CP, Weyermann C, Gassner AL. A study of transfer and prevalence of organic gunshot residues. Forensic Sci Int. 2017;277:241-51.

[46] Manganelli M, Weyermann C, Gassner AL. Surveys of organic gunshot residue prevalence: Comparison between civilian and police populations. Forensic Sci Int. 2019;298:48-57.

[47] Zeichner A, Levin N. Collection Efficiency of Gunshot Residue (Gsr) Particles from Hair and Hands Using Double-Side Adhesive Tape. J Forensic Sci. 1993;38:571-84. 